\title{
Determination of spawning areas and larval advection pathways for King George whiting in southeastern Australia using otolith microstructure and hydrodynamic modelling. I. Victoria
}

\author{
Gregory P. Jenkins $^{1, *}$, Kerry P. Black ${ }^{2}$, Paul A. Hamer ${ }^{1}$ \\ ${ }^{1}$ Marine and Freshwater Resources Institute, PO Box 114, Queenscliff, 3225 Victoria, Australia \\ ${ }^{2}$ Centre of Excellence in Coastal Oceanography and Marine Geology, Ruakura Satellite Campus, University of Waikato, \\ PB3105 Hamilton, New Zealand
}

\begin{abstract}
We used larval cluration estimated from otoliths of post-larval King George whiting Sillaginodes punctata collected from bays and inlets of central Victoria, Australia, and reverse simulation with a numerical hydrodynamic model, to estimate spawning sites and larval advection pathways. Larval duration increased from west to east for post-larvae entering Port Phillip Bay, Western Port and Corner Inlet. The period of recruitment to bays and inlets was relatively fixed $d_{i}$ the longer larval durations were associated with earlier spawning times. Larval durations for post-larvae entering Port Phillip Bay were longer for 1989 compared with 1994 and 1995. Reverse modelling based on larval durations for the 3 bays in 1995 suggested that most post-larvae were derived from spawning in western Victoria and southeastern South Australia. The centre of the predicted spawning distribution was ca 400 to $500 \mathrm{~km}$ from the recruitment sites and the region of intense spawning was spread along approximately $300 \mathrm{~km}$ of coastline. For Corner Inlet, however, a small proportion of the spawning may have occurred in central Victoria, within $200 \mathrm{~km}$ of the recruitment site, with larvae transported in a clockwise gyre around Bass Strait. The predicted spawning area for post-larvae from Port Phillip Bay was similar in the 3 yr examined.
\end{abstract}

KEY WORDS: Spawning area - Larval advection - Hydrodynamic numerical modelling - Otolith microstructure - Southeastern Australia - Sillaginodes punctata

\section{INTRODUCTION}

Rational management of fish populations depends on an understanding of stock structure (Sinclair 1988). Fundamental to understanding stock structure is information on spawning areas and the extent of egg and larval dispersal (Bailey 1997). The duration of the larval stage is a major factor that determines the potential for dispersal, and, for example, has been shown to be strongly correlated with genetic homogeneity of reef fish populations (Doherty et al. 1995). The actual extent of dispersal, however, depends on the interaction between larval duration and regional hydrodynamics; long larval

•E-mail: greg.jenkins@nre.vic.gov.au duration might not lead to wide dispersal if physical retention mechanisms are in place (Bailey 1997).

Recently, the use of numerical hydrodynamic models to study the influence of coastal oceanography on larval fish transport has increased (Bartsch \& Coombs 1997. van der Veer et al. 1998, Jenkins et al. 1999). Hydrodynamic modelling, together with knowledge of larval duration and other early life history parameters, can indicate the extent of larval dispersal from different spawning stocks, and may assist in the identification of spawning areas which provide recruitment to specific nursery areas (Pawson \& Jennings 1996). An example of this approach applies to abalone, where research incorporating larval biology and numerical hydrodynamic modelling has indicated that individual reefs 
are largely self-seeding and should be treated as individual stocks (Prince et al. 1987, McShane et al. 1988).

The King George whiting Sillaginodes punctata (Percoidei: Sillaginidae) is an important commercial species in southern Australia (Fig. 1). There is some evidence that sub-structuring of stocks occurs across the southern Australian coast based on parasites (Sandars 1945) and allozymes (Dixon et al. 1987). However, recent molecular DNA studies have provided no evidence for stock differentiation across southern Australia (L. Haigh \& S. Donnellan unpubl.).

Post-larvae of King George whiting appear in bays and inlets of Victoria from September to November each year (Robertson 1977, Jenkins \& May 1994). This stage is characterised by a full complement of fin elements but gut coiling has not begun and scales have not formed (Bruce 1995). At this stage, post-larvae are approximately 15 to $20 \mathrm{~mm}$ (Jenkins \& May 1994). The duration of the larval phase up to this point, determined from daily rings on otoliths of post-larvae collected in 1989, was approximately 90 to $150 \mathrm{~d}$, and the approximate spawning period was from May to early July (Jenkins \& May 1994). This extended larval period gives the potential for wide dispersal during this stage. Larval development occurs over the winter/spring period of strong westerly winds, suggesting that larvae would probably be transported from the west (Jenkins \& Black 1994, Jenkins et al. 1997).

Spawning of King George whiting does not appear to occur in bays and inlets of Victoria, because these populations are dominated by sub-adults, and there is an absence of eggs and larvae (Jenkins 1986, F. Neira unpubl.). In South Australia, young larvae are only found near the mouths of gulfs, whilst young juveniles are found deep within the gulfs (Bruce 1989). The only spawning aggregations identified to date in southern Australia were found near Kangaroo Island and southeast Spencer Gulf in South Australia (Fowler et al. 1999) (Fig. 1). The long larval period and strong current flow from the west over the larval period has led to the suggestion that post-larvae recruiting to Victorian inlets may originate from spawning as far away as South Australia (Jenkins \& May 1994). At present it is not known whether recruits to different bays and inlets of Victoria are derived from similar or different spawning areas. Such knowledge would allow us to determine whether bays and inlets should be managed as individual stocks or as part of a single stock.

This and the companion paper (Fowler et al. 2000, in this issue) aim to predict the approximate spawning area(s) and larval advection pathways of King George whiting in southeast Australian waters. Predictions are based on estimates of larval duration determined from otolith microstructure of post-larvae, and 'reverse' tracking to the spawning ground using a numerical hydrodynamic model that incorporates real climatic information. This paper is concerned with spawning areas and larval advection for recruits in the Victorian region, and the companion paper addresses the same issues for South Australia. Here, results are compared for post-larvae collected from 3 bays along the Victorian coast and also for post-larvae collected in 3 yr from Port Phillip Bay.

\section{MATERIAL AND METHODS}

Study area. The region of interest was the coastal waters of Victoria and south-east South Australia (Fig. 1). This area is dominated by Bass Strait, an
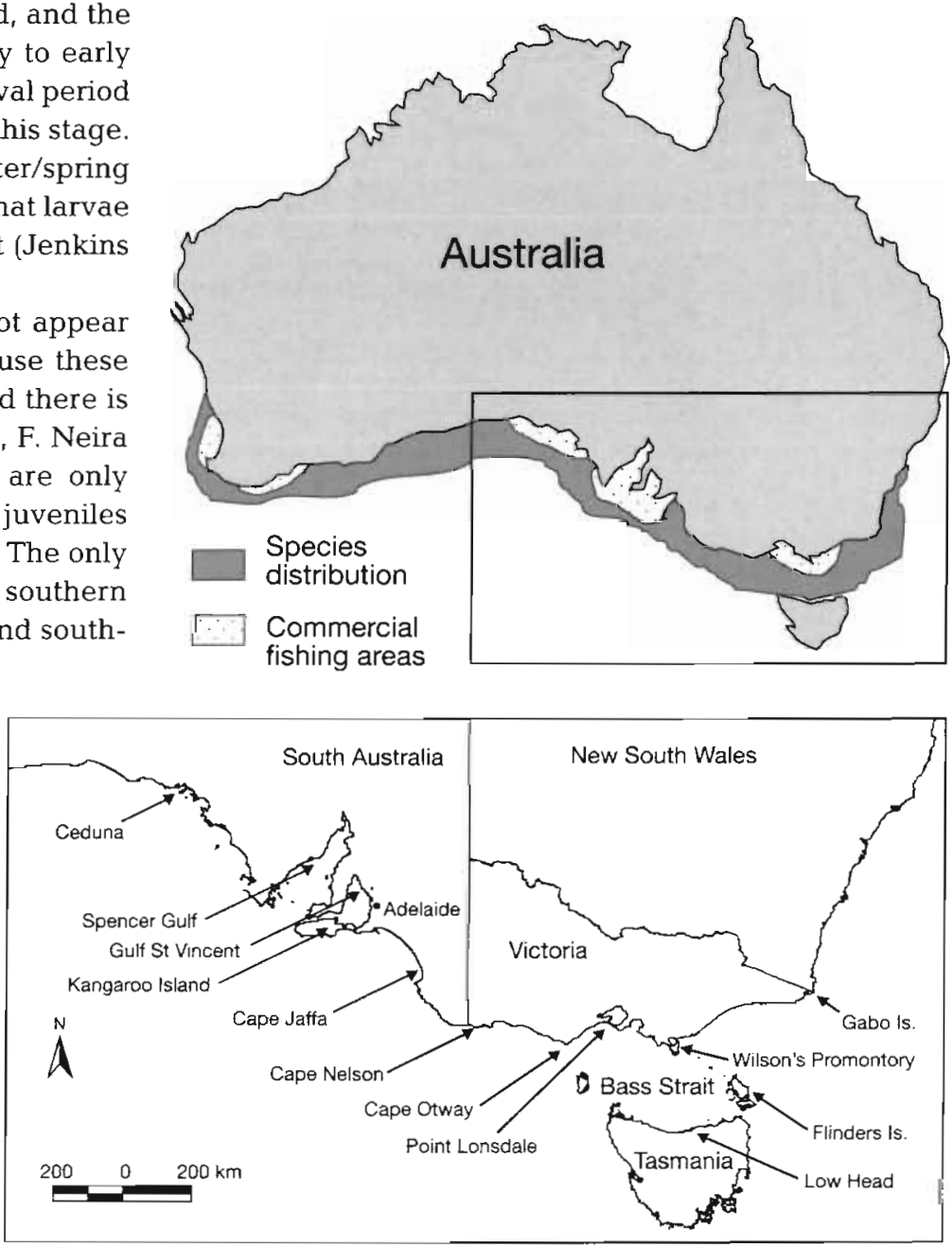

Fig. 1. Distribution of King George whiting around southern Australia, and the location of major fishery areas 
approximately rectangular water body some 400 by $200 \mathrm{~km}$ in extent. The Strait consists of a shallow platform, mostly about $70 \mathrm{~m}$ below sea level, flanked by an ocean 4 to $5 \mathrm{~km}$ deep to the east and west and by land to the north and south. Although tidal currents can be strong in certain areas, such as the eastern and western entrances to Bass Strait (Black 1992), the net tidal circulation tends to be small and tidal currents would have little influence on dispersal of long-lived larvae. The primary determinants of net water movement in the region are wind-driven currents and coastal trapped waves (Middleton \& Black 1994). The density structure of Bass Strait ranges from well mixed in winter to strongly stratified in central areas in summer (Baines \& Fandry 1983).

Sample sites. Sampling for King George whiting post-larvae was conducted in Port Phillip Bay, Western Port and Corner Inlet, Victoria, in 1995 (Fig. 2). In Port Phillip Bay, post-larval King George whiting were collected by plankton net at 2 sites (BWS1, BWS11) immediately inside Port Phillip Heads from September to November (Jenkins et al. 1999, Fig. 2). In Western Port, post-larvae were collected from beds of the seagrass Heterozostera tasmanica at Cribb Point, Rhyll and Corinella; whilst in Corner Inlet, post-larvae were collected from $H$. tasmanica beds at Welshpool, Toora and Yanakie (Fig. 2).

In addition to samples collected in 1995, otoliths were also examined from post-larvae that had been previously collected by plankton net from BWS1 in Port Phillip Bay between September and November 1994 (Jenkins et al. 1999). Additional otolith data for 1994 were obtained from specimens that were collected in seagrass immediately inshore from the plankton sampling site in the study by Jenkins et al. (1998a). Finally, otolith data for 1989 were obtained from postsettlement specimens collected from Swan Bay and described by Jenkins \& May (1994).

Field sampling methods. Post-larval Sillaginodes punctata collected in seagrass were sampled using a $10 \mathrm{~m}$ long, $2 \mathrm{~m}$ deep, beach seine with a $1 \mathrm{~mm}^{2}$ mesh. Two $10 \mathrm{~m}$ ropes were attached to each end of the net that was then hauled over this distance. Two persons hauled the net into a plastic bin that was then transferred to shore or boat to sort the sample. Post-larval S. punctata were placed in $95 \%$ ethanol to preserve otoliths. Replicate, non-overlapping hauls were conducted until an adequate sample size was obtained. Sampling was conducted approximately $2.5 \mathrm{~h}$ each side of low tide and each bay was sampled over a 2 to $3 \mathrm{~d}$ period. The depth of sampling was approximately 0.25 to $0.5 \mathrm{~m}$ below the mean-low-water-spring level.

Post-larval King George whiting in the plankton were sampled with a $4 \mathrm{~m}$ long plankton net constructed of $1 \mathrm{~mm}^{2}$ mesh attached to a $1 \times 1 \mathrm{~m}$ square frame. The towing cable was connected to a chain bridle attached to the top corners of the net frame. A $16 \mathrm{~kg}$ depressor weight was attached to a chain bridle on the bottom of the net. The towing speed was approximately $1 \mathrm{~m} \mathrm{~s}^{-1}$, producing an angle of attack of the net of approximately $30^{\circ}$ and an effective mouth area of $0.9 \mathrm{~m}^{2}$. Tow duration was $15 \mathrm{~min}$. Again, samples were placed in $95 \%$ ethanol to preserve otoliths.

Laboratory methods. In the laboratory, otoliths were dissected from fish and examined under a compound microscope with attached video system using the techniques described by Jenkins \& May (1994). A total of 113 post-larvae from Port Phillip, 97 from Western Port and 83 from Corner Inlet had otoliths with increments sufficiently clear to interpret and analyse. In addition, otoliths from 55 post-larvae collected from Port Phillip Bay in 1994, and 51 collected in 1989, were analysed. In some cases, otoliths from specimens from Western Port and Corner Inlet were ground and polished to increase the clarity of increments. Otoliths were mounted, proximate surface down, on microscope slides in epoxy resin and ground and polished on a lapping wheel, initially with 1000 grade wet and dry paper, and final polishing to the primordium with $6 \mu \mathrm{m}$ dia-

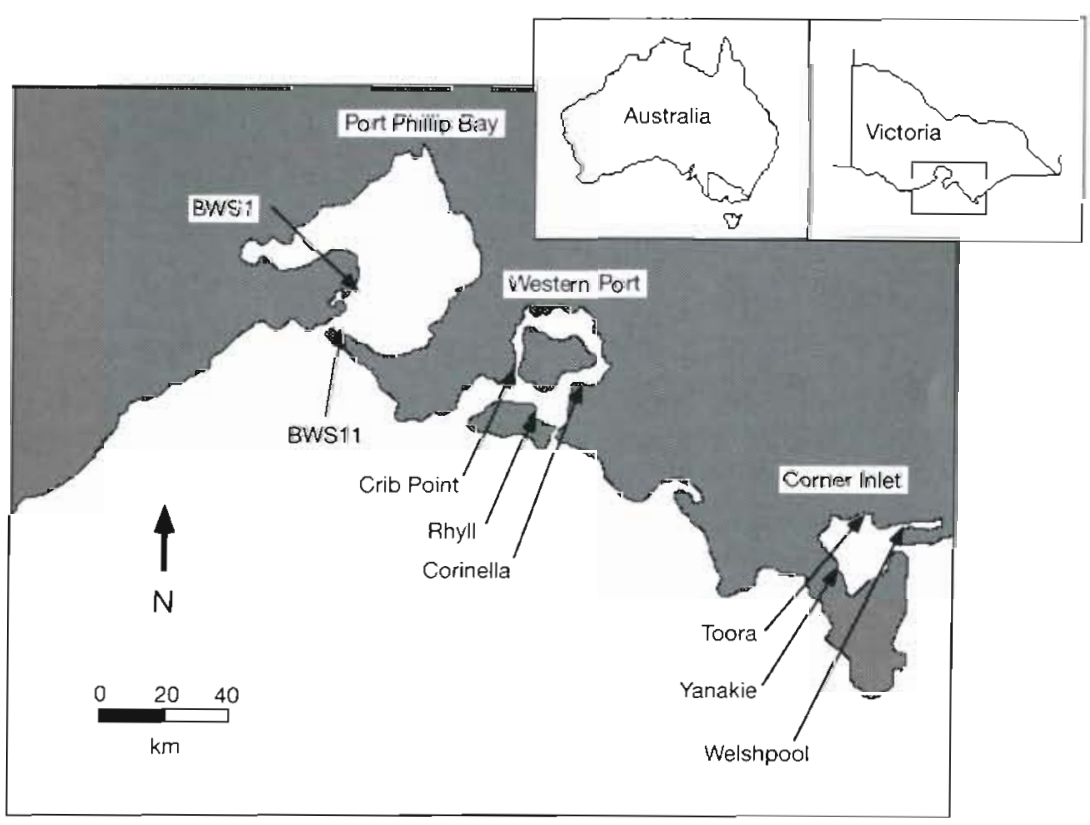

Fig. 2. Sampling sites for post-larval King George whiting in Port Phillip Bay, Western Port and Corner Inlet. Insets: Position of the study area on the Victorian coast, and location of the State of Victoria in Australia 
mond paste. Increment counts were done twice, the second reading blind with respect to the result of the first. If there was a discrepancy of more than 5 increments, a third reading was done. If all 3 readings differed as described, the otolith was rejected; if 2 of the counts were within the specified range, then the average of those 2 counts was used.

In many post-larvae, otoliths contained a transition in microstructure, signified by a rapid increase in increment width, that occurs at approximately the time of entry to the bay or inlet (Jenkins \& Black 1994, Jenkins \& May 1994). The number of increments counted outside the transition was subtracted from the date of capture to give the approximate arrival date of an individual to a bay, thus providing an estimate of the period of larval drift from the spawning ground to the particular bay. Five days, the approximate time from hatching to first feeding when the first increment is formed, was added to the increment count to give the hatch date (Jenkins \& May 1994).

Numerical modelling. The western boundary of the model grid was placed near Ceduna, South Australia (Fig. 1) using the boundary condition techniques proved by Middleton \& Black (1994). This involved adding coastal-trapped wave oscillations to the boundary sea levels using measured coastal water levels at Thevenard (Ceduna). Measured winds were taken from Ceduna, Cape Borda (Kangaroo Island), Cape Nelson (Portland), Cape Otway, Wilson's Promontory, Flinders Island, Low Head (Tasmania) and Gabo Island (Fig. 1) and interpolated using inverse distance weighting (Black 1995) onto each model cell. For model verification, predicted sea levels were compared with actual sea levels at Port Stanvac (Adelaide), Portland (Cape Nelson) and Point Lonsdale (Fig. 1). The sea level indicates the current strength along the shelf due to set-up and set-down caused by the Coriolis force.

We used the 3-dimensional hydrodynamic model 3DD (Black 1995) and dispersal model POL3DD (Black 1996). The 3-dimensional hydrodynamic model had 6 depth strata: $0-5$, $5-15,15-35,35-55,55-75$, and 75-6000 $\mathrm{m}$. The model region was based on a grid of $10 x$ $10 \mathrm{~km}$ square cells, 178 cells east to west by 91 cells north to south. In the dispersal model the horizontal eddy diffusivity was set at $0.0015 \mathrm{~m}^{2} \mathrm{~s}^{-1}$. The period simulated was from March 1 to November 30 of each year. Simulations in 1995 included all 3 bays but in 1994 and 1989, simulations were based on data from Port Phillip Bay only. Larvae were modelled as neutrally buoyant and moving randomly throughout the depth range, which gave the broad limits of the spawning distribution and larval transport of the species.

All post-larvae from the 3 bays that were successfully aged were represented in the model to simulate the actual larval advection based on measured larval durations and arrival dates. To improve statistical reliability each larva was represented by 10 neutrally buoyant particles that were seeded at the mouth of a bay or inlet on their estimated day of arrival. Particles were then tracked for their estimated larval duration in a 'reverse' simulation to the point of hatching. The advection pathway and final (hatching) position was plotted in space for all particles.

To examine the possible influence of larval behaviour on advection pathways and predicted spawning areas, a diurnal vertical migration scenario was imposed on the particles in a second series of simulations.
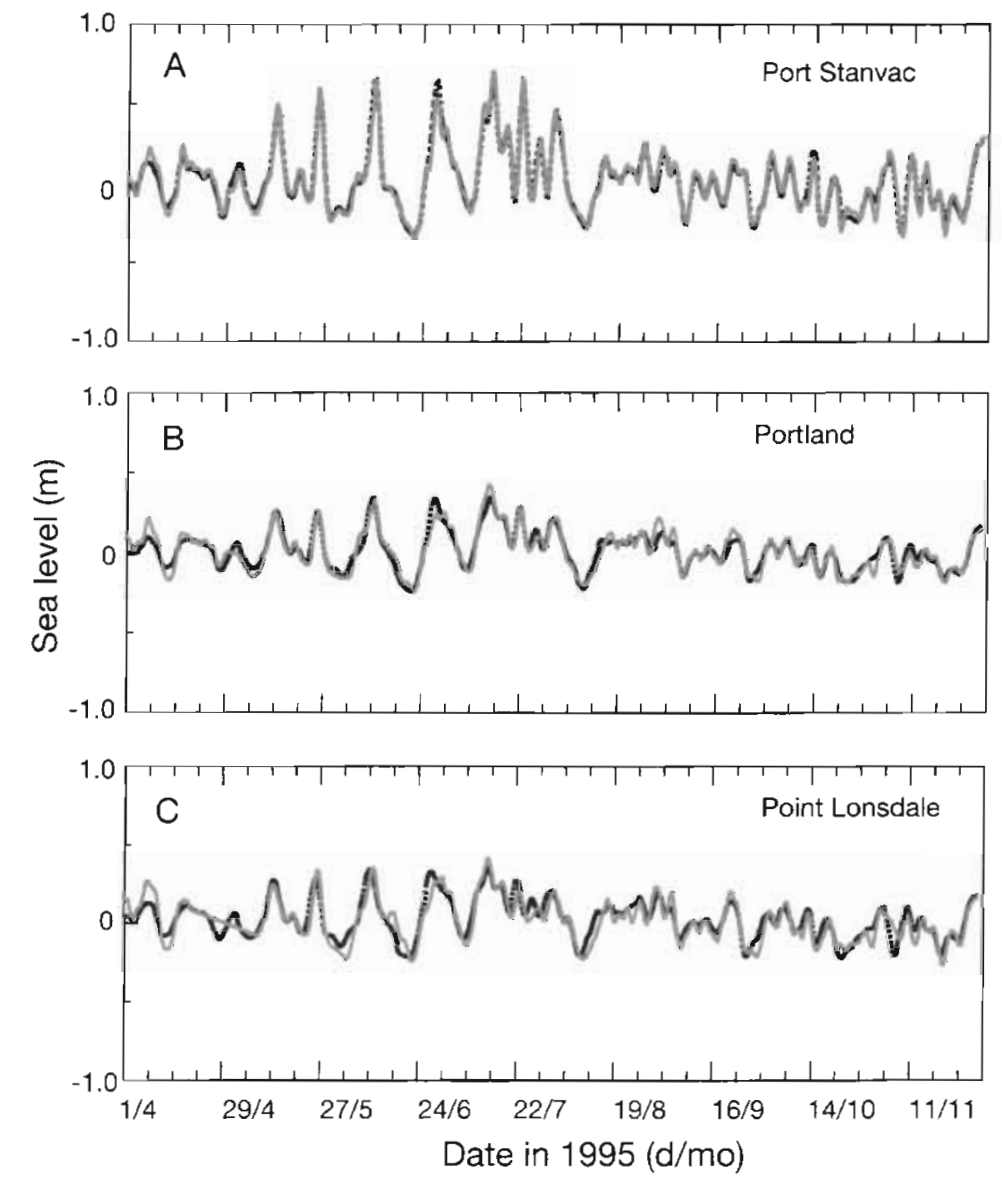

- Smoothed model run Smoothed residual sea level

Fig. 3. Correspondence between actual (black) and predicted (grey) residual sea levels at (A) Port Stanvac, South Australia, (B) Portland, Victoria, and (C) Point Lonsdale, Victoria, for the period April 1 to November 30, 1995 
This involved a 'reverse' diurnal migration as has been found for Sillaginodes punctata post-larvae in Port Phillip Bay (Jenkins et al. 1998b). In this simulation, particles were randomly mixed within the upper $5 \mathrm{~m}$ of the water column in daylight, and within the upper $75 \mathrm{~m}$ at night.

Hydrodynamic model calibration compared the predicted and observed residual sea level (low frequency sea level oscillations) at Point Lonsdale and Portland (Cape Nelson) in Victoria, and Port Stanvac (Adelaide) in South Australia (Fig. 1). Low frequency sea levels indicate the mass water movements in and around Bass Strait that primarily govern larval dispersal over long time periods. The model was skilful in predicting sea level at all 3 sites (Fig. 3), but was most accurate in the west, nearer to the western boundary. Overall, the model showed a high degree of accuracy in predicting sea level, supporting previous similar calibrations of sea levels and current speeds (Hammond et al. 1994, Middleton \& Black 1994). The good calibration results indicate that the model satisfactorily simulates the propagation of continental shelf waves past the gulfs of South Australia and into Bass
Strait (Fig. 1). These shelf waves, together with local wind-driven currents, are primarily responsible for the sea level response and the larval advection excursions.

\section{RESULTS}

\section{Comparison amongst bays in 1995}

Larval durations estimated from otoliths varied significantly amongst bays (ANOVA, $\mathrm{df}=2 / 290, F=62.07$, $\mathrm{p}<0.001$ ) in 1995, with a mean duration of $119 \mathrm{~d}$ for Port Phillip, $128 \mathrm{~d}$ for Western Port, and $138 \mathrm{~d}$ for Corner Inlet. Post-hoc testing indicated that all bays differed significantly from each other (Tukey's HSD, $p<0.001)$. There was a trend for increasing larval duration from west to east (Fig. 4A).

Hatch date estimated from otoliths also varied amongst bays, with a median hatch date of June 10 for post-larvae in Port Phillip Bay, May 29 for Western Port, and May 21 for Corner Inlet (Fig. 4B). The spawning period was late April to late July for post-larvae in
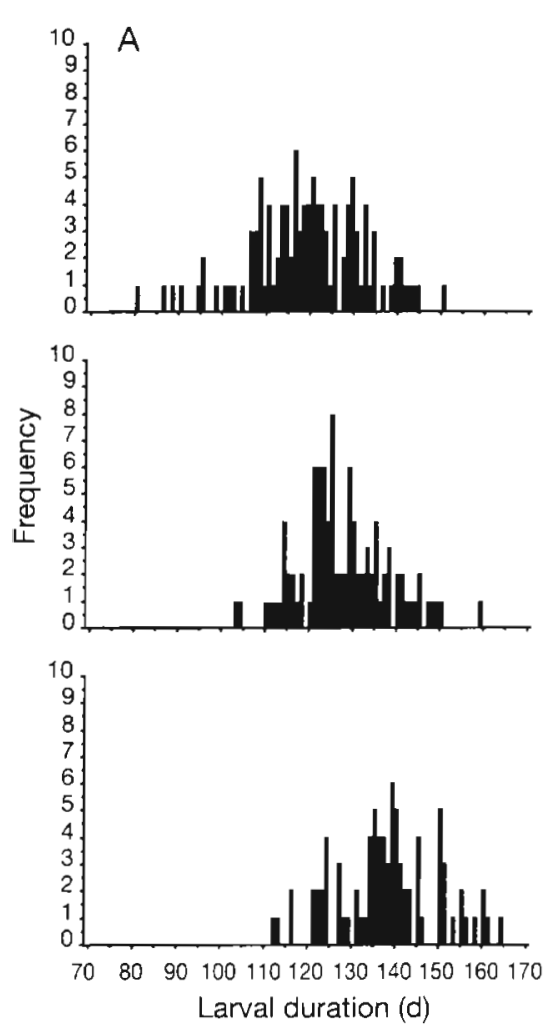
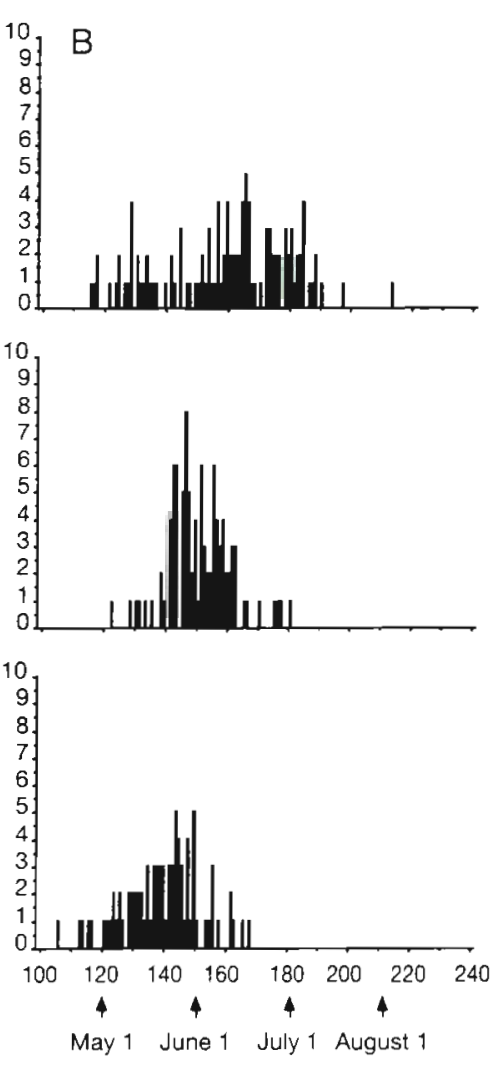

Hatch date (day of the year)
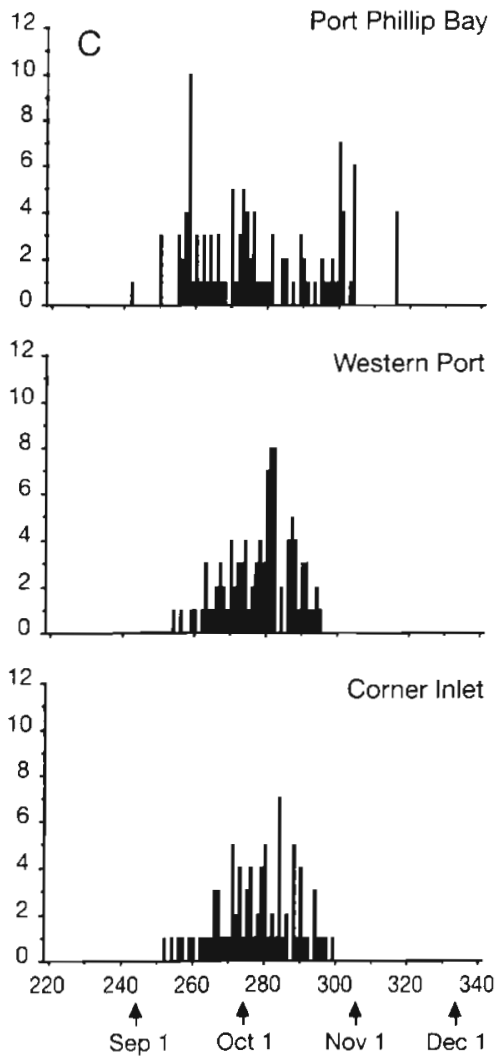

Date of otolith transition (day of the year)

Fig. 4. (A) Larval duration, (B) date of hatching, and (C) date of otolith transition, estimated from otoliths for post-larval King George whiting from 3 bays in 1995 
Port Phillip Bay, early May to early July in Western Port and mid-April to mid-June for Corner Inlet (Fig. 4B). There was a trend for earlier spawning for post-larvae from west to east (Fig. 4B). The variability and spread of the distribution for Port Phillip was greater than for Western Port or Corner Inlet (Fig. 4B).

The median date of arrival at the bays was very similar for Western Port ( 7 October) and Corner Inlet (6 October), but was slightly earlier for Port Phillip (1 October) (Fig. 4C). Arrival of post-larvae occurred from late August to early November in Port Phillip Bay, and mid-September to late October in both Western Port and Corner Inlet (Fig. 4C). As was the case with hatching dates, the variability and spread of the distribution for Port Phillip was greater than for Western Port or Corner Inlet (Fig. 4C).

\section{Comparison amongst years}

Larval durations estimated from otoliths varied significantly amongst years for Port Phillip (ANOVA, df = $2 / 216, F=19.203, p<0.001$ ), with a mean duration of $119 \mathrm{~d}$ for 1995, $121 \mathrm{~d}$ for 1994, and $132 \mathrm{~d}$ for 1989 (Fig. 5A). Post-hoc testing indicated that larval duration for 1994 and 1995 was not significantly different, but 1989 was different from the later years (Tukey's HSD, $p<0.001)$. Thus, larval durations in 1989 were longer than in the other 2 years (Fig. 5A).

Hatch date estimated from otoliths also varied amongst years for post-larvae in Port Phillip Bay, with a median date of June 10 for 1995, June 5 for 1994 and May 21 for 1989 (Fig. 5B). Thus, the median hatch date in 1989 was earlier than in the other 2 years (Fig. 5B). Hatching dates ranged from late April to late July in 1995, late April to mid-July in 1994, and mid-April to mid-July in 1989 (Fig. 5B).

The median date of arrival at Port Phillip for the 3 years was similar, October 1 for 1995, September 29 for 1994 and September 25 for 1989 (Fig. 5C). Arrival dates ranged from early September to early November in 1994 and 1995, and mid-September to early November in 1989 (Fig. 5C). Although arrival of post-larvae was highly variable in each year, arrival in 1989 was characterised by pulses that occurred on a 10 to $14 \mathrm{~d}$ period (Fig. 5C).
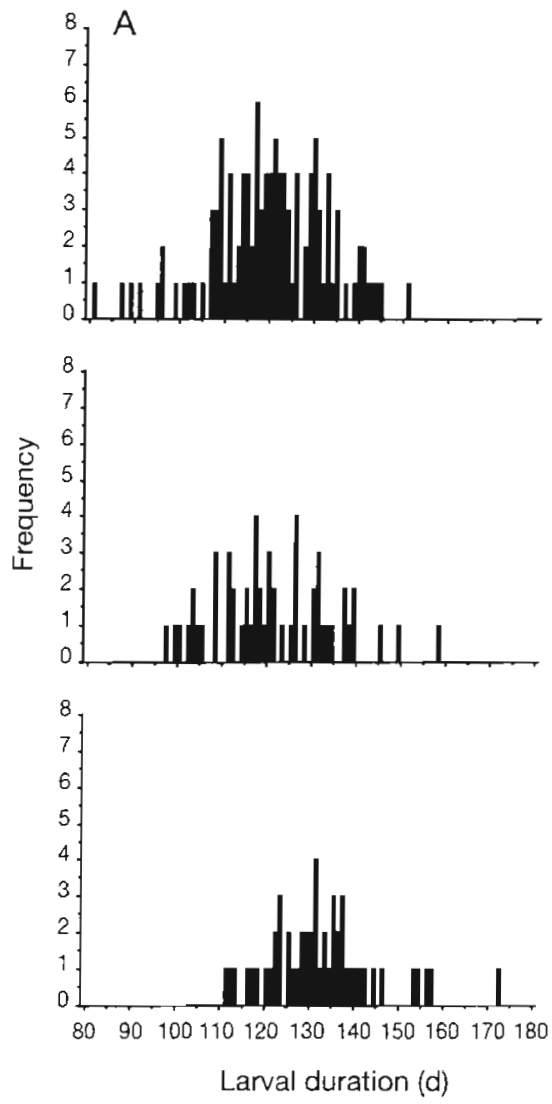
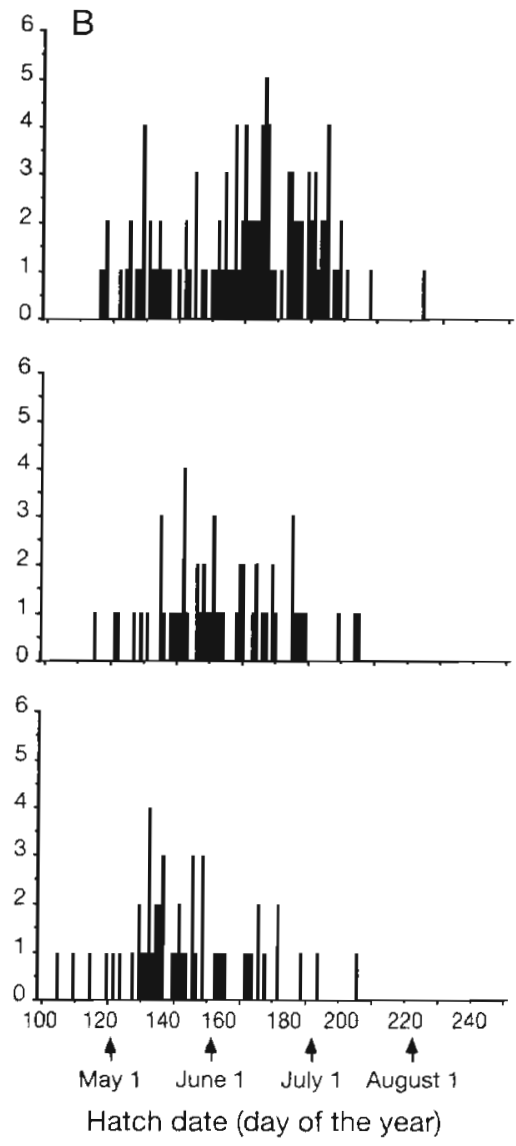
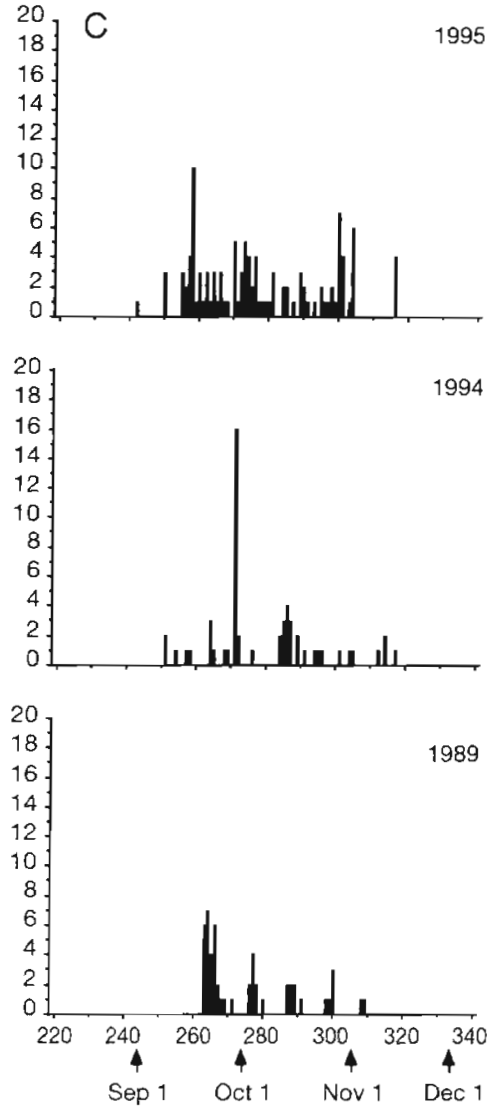

Date of otolith transition (day of the year)

Fig. 5. (A) Larval duration, (B) date of hatching, and (C) date of otolith transition, estimated from otoliths of past-larval King George whiting from Port Phillip Bay for 3 years 


\section{Reverse modelling}

\section{Simulation of currents}

The mean current velocities and directions for the surface layer predicted by the hydrodynamic model are presented for the 3 years in Fig. 6. In the western part of the grid near the South Australian Gulfs the currents are generally weak and non-directional. Along the western coast of Victoria currents are slightly stronger and are uni-directional from west to east. Strong currents run north along the western boundary of Bass Strait and turn to follow the coast from west to east through northern Bass Strait and eastern Victoria. A clockwise gyre is apparent within Bass Strait. The major difference amongst years was that currents in Bass Strait and eastern Victoria in 1989 were weaker than in the other 2 years (Fig. 6).

\section{Comparison of bays in 1995}

The predicted spawning areas for recruits to the individual bays are shown in Fig. 7. The simulation for Port Phillip Bay recruits showed the majority of the spawning to occur along the coast from west of Cape Otway to Cape Jaffa (ca $300 \mathrm{~km}$ ). Spawning was most concentrated around Cape Nelson, a distance of approximately $400 \mathrm{~km}$ from the recruitment site, with a very low level of spawning predicted for the western boundary of Bass Strait (Fig. 7A). The simulation for Western Port recruits showed a similar pattern to Port Phillip recruits, although a greater level of spawning was predicted to occur along the western boundary of Bass Strait (Fig. 7B). The simulation for Corner Inlet recruits gave a markedly different pattern, with predicted spawning not extending as far west along the coast, but showing high levels along the western boundary of Bass Strait and low levels in central and eastern Bass Strait (Fig. 7C). The highest intensity of predicted spawning, however, was still located near Cape Nelson, approximately $500 \mathrm{~km}$ from Corner Inlet (Fig. 7C).

To investigate the larval advection pathways associated with the predicted spawning areas in the 3-D simulations, we also plotted the integrated numbers of particles throughout each simulation (the position of particles throughout the simulation is recorded and presented on a single graph). As expected, the Port Phillip Bay simulation showed a concentration of particles from Port Phillip Bay along the coast to the predicted spawning area
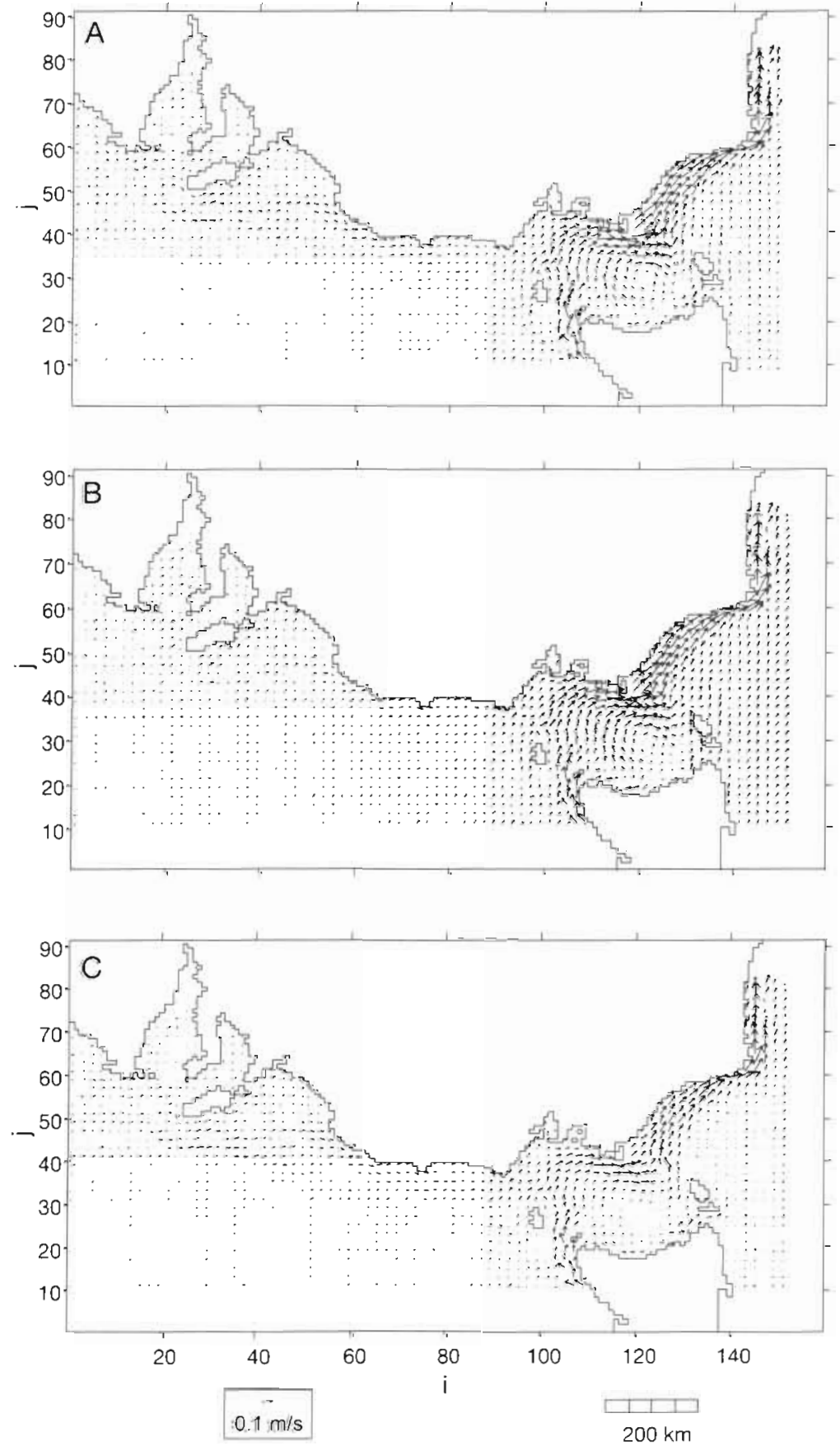

Fig. 6. Mean current velocities and directions for the surface layer predicted by the hydrodynamic model for the period June 1 to October 1, in (A) 1995,

(B) 1994, and (C) 1989. ' $i$ ': grid cell number from west to east ${ }_{i}$ ' $j$ ': grid cell number from south to north 

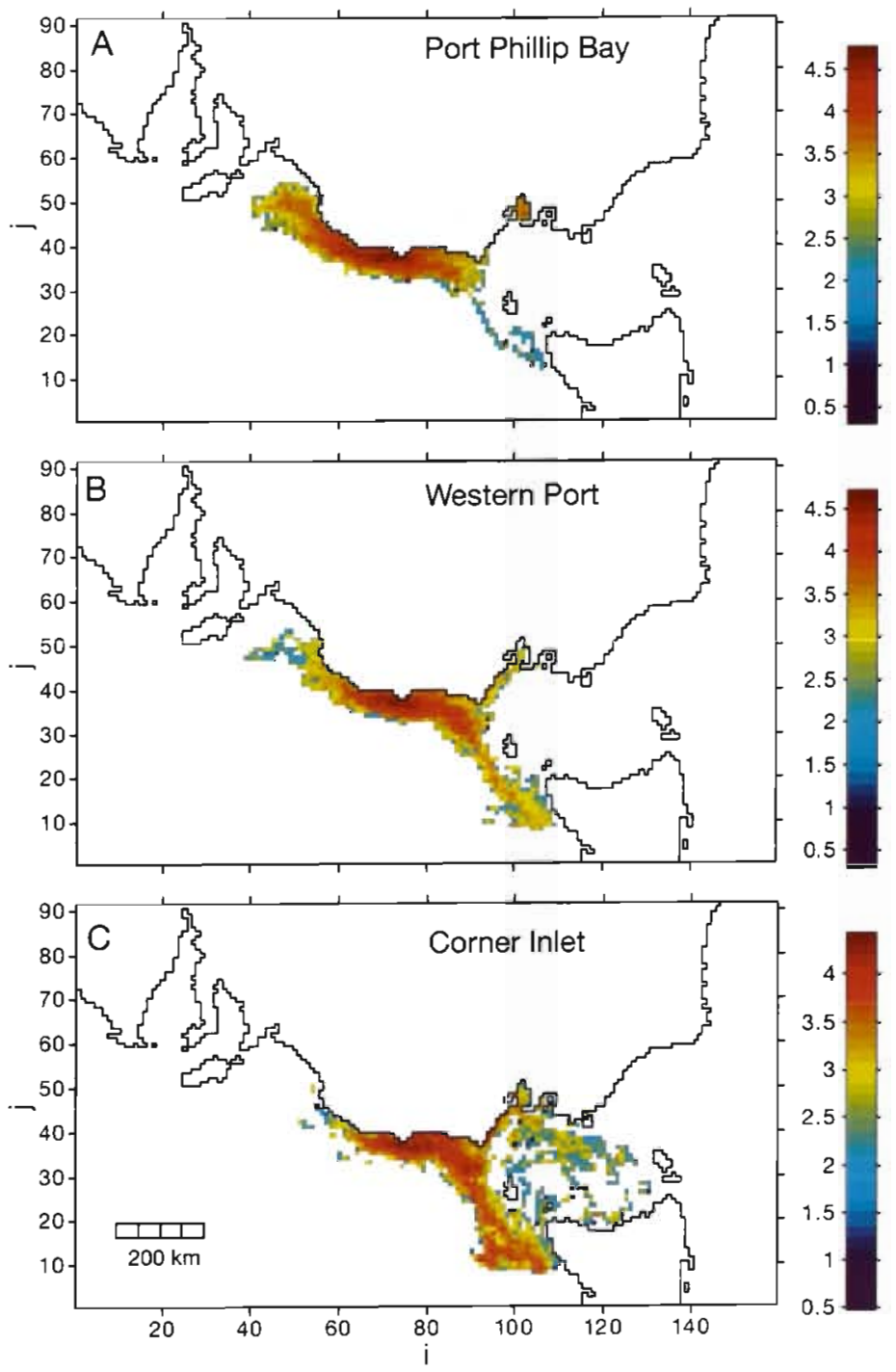

Fig. 7. Predicted spawning area of King George whiting for post-larvae from (A) Port Phillip Bay, (B) Western Port, and (C) Corner Inlet, in 1995 based on reverse hydrodynamic modelling. Scale bar: log particle density; ' $i$ ': grid cell number from west to east ${ }_{i} j$ ': grid cell number from south to north

(Fig. 8A). The Western Port simulation showed a concentration of particles along the coast and also a bifurcation down the western boundary of Bass Strait to north-western Tasmania (Fig. 8B). The Corner Inlet simulation was similar to Western Port but also showed an advection pathway that looped around the western boundary of Bass Strait and northern Tasmania to central Bass Strait (Fig. 8C). This latter pathway suggests that recruits in Corner Inlet could be derived from spawning on the nearby coast, with larval advection in a clockwise gyre down to northern Tasmania, northwards along the western boundary of Bass Strait, and eastwards along the Victorian coast to Corner Inlet (Fig. 8C).

\section{Comparison of years}

Otolith data for Port Phillip Bay in all 3 years gave very similar spawning distributions, ranging from approximately Cape Otway to the west of Cape Jaffa (Figs. 7A \& 9). The most concentrated spawning is predicted to be close to the coast in the vicinity of Cape Nelson in all years (Figs. 7A \& 9).

\section{Larval behaviour}

The addition of a vertical migration scenario to the simulation had the effect of moving the predicted
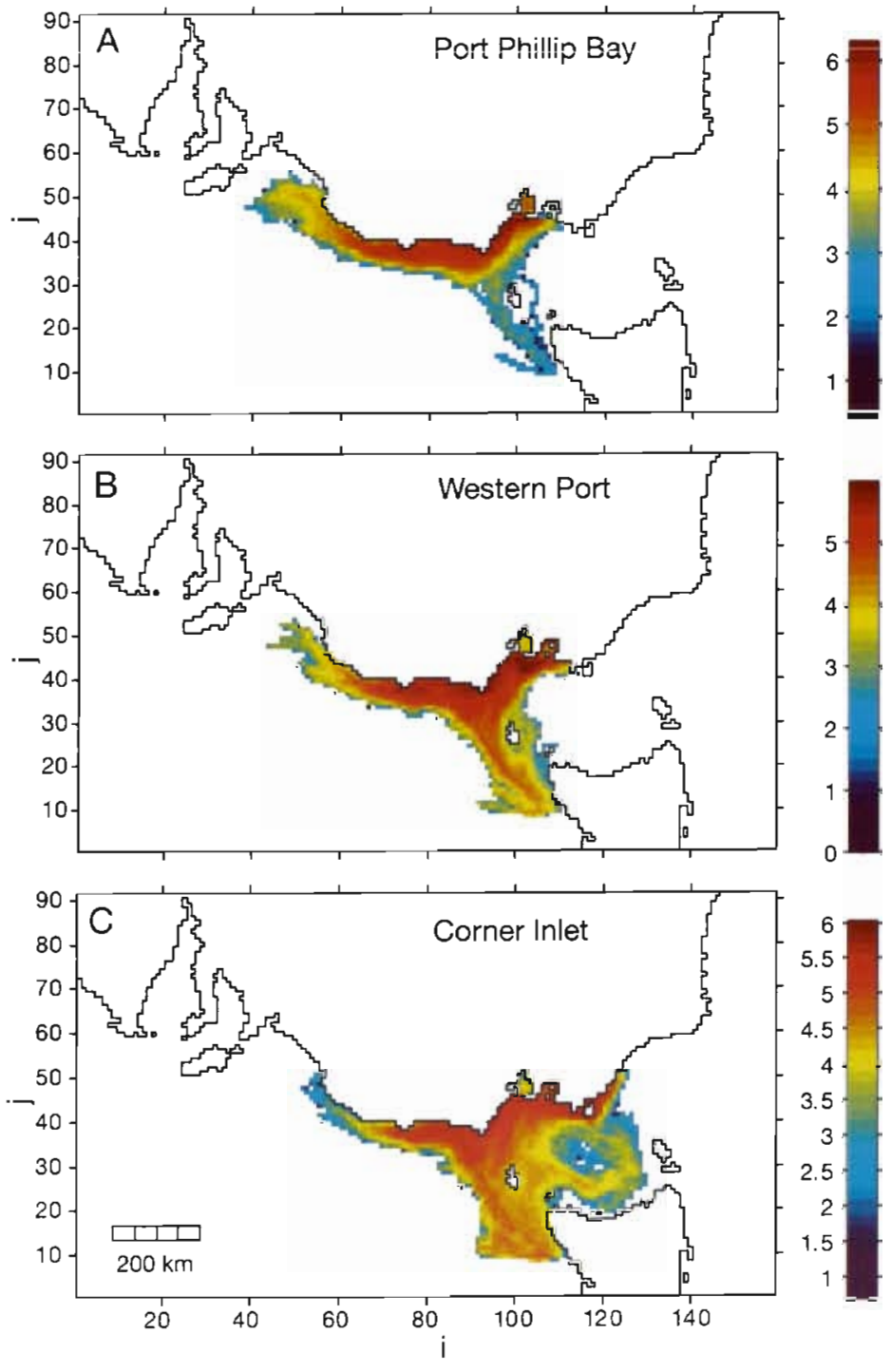

Fig. 8. Predicted advection pathway for King George whiting post-larvae entering (A) Port Phillip Bay, (B) Western Port and (C) Corner Inlet, in 1995 based on reverse hydrodynamic modelling. Scale bar: log particle density; ' $i$ ': grid cell number from west to east; ' $\mathrm{j}$ ' grid cell number from south to north 

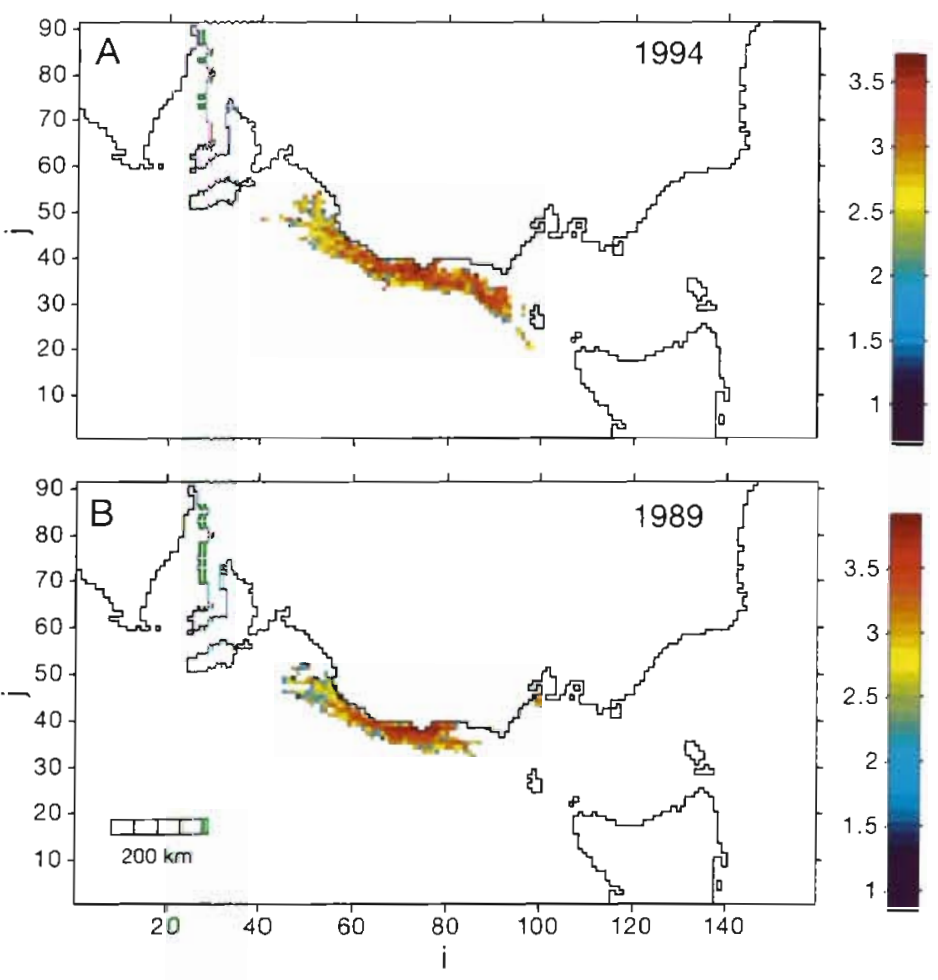

Fig. 9. Predicted spawning area of King George whiting for post-larwa e from (A) Port Phillip Bay in 1994, (B) 1989, based on reverse hydrodynamic modelling. Scale bar: log particle density; 'i': grid cell number from west to east; ' $j$ ': grid cell number from south to north

spawnimg area offshore, and reducing the spread of spawning in an east-west direction (Fig. 10). Vertical migration did not result in a quantitative shift of the spawning area along the coast (Fig. 10).
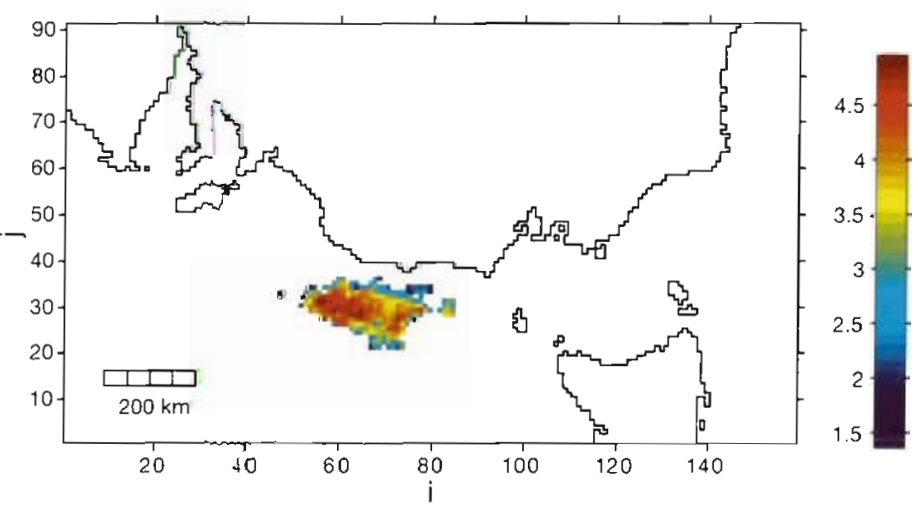

Fig. 10. Predicted spawning area of King George whiting for post-larvae from Port Phillip Bay in 1995 based on reverse hydrodyazmic modelling including a diurnal vertical scenario applied to particles. Scale bar: log particle density; ' $i$ ': grid cili number from west to east; ' $j$ ': grid cell number from south to north

\section{DISCLESTON}

Numerical hydrodyname modelling is increasingly being used as a tool to excruine larval dispersal, particularly in relation to recruitment variation (Bartsch \& Coombs 1997, Heath et El. 1998, Heath \& Gallego 1998, Proctor et al. 1998, varj der Veer et al. 1998). We have previously used a numerical model of passive dispersal to successfully predict transport patterns of post-larval King George whiting in Port Phillip Bay (Jenkins et al. 1999). This stmidy has shown that the combination of 'reverse' hydrodynamic modelling and otolith microstructure can tee a useful tool for identifying possible spawning anteas and indicating stock structure for species where this is not known.

The major predicted spa.wrtuing area for post-larvae from all bays and years, wasi the western coast of Victoria and the southeasterm comast of South Australia. This result is consistent even though larval durations and spawning times varied amongst bays and amongst years. These results suggest that this area should be targeted for adult reproductiwe and egg and larval surveys to test model predictions. The closest confirmed spawning areas for Sillagir odes punctata are northern Kangaroo Island and southerm Spencer Gulf (Fowler et al. 1999, Fig. 1), hundrecis of kilometres west of the furthest western extent of predicted spawning estimated for post-larvae in Vhetoria. The habitat apparently favoured by spawniog King George whiting, deep reefs or mounds up tio a depth of $50 \mathrm{~m}$ in relatively exposed waters neart the coast (Hyndes et al. 1996, 1998, Fowler et al. unpoubl.), would be well represented in the predicted sfawning area.

Although there were som differences in the spawning period predicted from postt-larvae collected in the 3 yr and amongst the 3 bays in 1995, the general period of spawning between Aprîl and July was relatively consistent. This spawning period can be compared to that predicted for South Australian and Western Australian fisheries based on ac sllt reproductive indices. In South Australia, spawning occurred from March to May, with a peak in April (Fywler et al. 1999), approximately 1 mo to 6 wh ear than estimated in this study. In Western Australia, spawning is estimated to occur between June and Smptember (Hyndes et al. 1998), considerably later the for Victorian or South Australian stocks. The inconsistency in spawning periods estimated from gonad dervelopment in South Australia compared with estimattes from otolith microstructure in Victoria reported here further suggests that post-larvae in the 2 areas maty not be derived from the same spawning stock.

Arrival times of post-larwe at bays and amongst years were remarkably consistent in Victorian waters. The comparison amongst berss in 1995 showed that 
when larvae were subjected to similar conditions of larval transport, larval duration increased and spawning time was correspondingly earlier for post-larvae recruiting to bays further to the east. This reflected the greater distance that would need to be travelled from a common spawning ground to more eastern recruitment sites. It is interesting that rather than spawning occurring at one time and recruits arriving progressively later to bays further to the east, recruits tended to arrive at bays at the same time. Thus, the further to the east recruitment occurs, the earlier in the spawning season the recruits are derived from. This implies there is a 'window of opportunity' for recruitment before and after which recruitment cannot occur. Thus, rather than the recruitment period changing from year to year, the spawning period (or period within the spawning season) may vary from year to year depending on transport processes. The simultaneous arrival within the bays may relate to favourable environmental conditions for entry into the bay (rising low frequency water levels in alssociation with west winds) as described by Jenkins et al. (1997).

When predicted spawning was compared amongst years for recruits to Port Phillip Bay the arrival times of post-larvae were consistent, but larval duration in 1989 was significantly longer and spawning was earlier than in the other years. These results probably reflect varying rates of larval transport amongst years, with a reduced rate of transport in 1989, reflected by the lower current strengths in this year, resulting in longer larval duration. Interannual differences in larval transport are most likely related to variation in variables such as the strength of the westerly wind field, forced by factors such ass the El Niño/Southern Oscillation. Such interasmual variation in larval transport may have major implications for recruitment. The strength of the westerly wind field across southeastern Australia has been shown to correlate strongly with recruitment variability in important fisheries (Harris et al. 1988, Thresher 1994).

Modelling suggested that spawning areas other than the coast of western Victoria and southeastern South Australia were possible, particularly for recruits to Western Port and Corner Inlet. A caveat on the results is that the modelling will show all potential sites of spawning that could result in recruits arriving at a particular time and site, but in reality all such sites may not be spawning sites. Adult King George whiting are common on the rocky exposed coast of western Victoria and southeastern South Australia, and are also recorded on the northern Tasmanian coast and the Victorian coast between Port Phillip Bay and Corner Inlet. In contrast, there is little evidence that adult King George whiting occur in deep water along the western boundary of Bass Strait. The results imply some pos- sible segregation of stocks, particularly between Port Phillip Bay and Corner Inlet, because recruits to Port Phillip are derived from spawning in western Victoria, but recruits to Corner Inlet may be derived from central as well as western Victoria. To a small extent Corner Inlet may be 'self-seeding' if adults spawning on the central Victorian coast were derived from Corner Inlet. Our results are consistent with the fact that juvenile and adult King George whiting are rare to the east of Corner Inlet.

A factor that might modify the results of simulations is larval behaviour. We have demonstrated that postlarvae of King George whiting entering Port Phillip Bay show strong diurnal vertical migration, and also weak tidal vertical migration (Jenkins et al. 1998b). Larvae are concentrated near the surface during daylight and tend to be randomly distributed through the water column at night. Our simulation involving a vertical migration scenario showed no tendency to shift the predicted spawning area to the west. However, the concentration of spawning was further offshore, suggesting that surface currents had a greater northerly directional component over the larval period than deeper currents. In general, evidence from other States suggests that spawning near the coast, as predicted by the 'passive' model, would be more likely than spawning offshore (Hyndes et al. 1998, Fowler et al. 1999). Jenkins et al. (1999) found that predictions of spatial distribution of post-larval Sillaginodes punctata in Port Phillip Bay were more accurate for 'passive' simulations compared with those incorporating larval behaviour. One reason that predictions may not be accurate based on behaviour of post-larvae is that vertical migration is likely to be less developed in younger larvae (Neilson \& Perry 1990, Heath et al. 1991, Champalbert \& Koutsikopoulos 1995).

The results presented in this study are relevant to any species that settle along the Victorian coast and have a relatively long larval duration. In terms of the recent invasion of central Victorian bays by exotic species (Wilson et al. 1998, Currie \& Parry 1999), the results show that transport of larvae along the coast between bays would be relatively rapid from west to east in the winter/spring period. Furthermore, the transport of larvae from Tasmanian to Victorian coasts is a distinct possibility.

In summary, King George whiting in Victorian waters are probably part of a single, broad-ranging stock that spawns along the coast of western Victoria and southeastern South Australia. Thus, populations of King George whiting in Victorian bays and inlets should, in general, be managed as a single stock. The results of this study can now be used as a basis for studies aimed at confirming the spawning areas and times of King George whiting in Victorian and south- 
east South Australian waters. The results could be used to plan ichthyoplankton surveys targeting eggs and larvae of King George whiting, or a study of adult reproductive condition, aimed at determining spawning areas and times, and reproductive parameters such as sex ratio, fecundity, and egg production (Hyndes et al. 1998, Fowler et al, 1999).

Acknowledgements. We are indebted to David Hatton for his tireless work running models. We were assisted in the field by Tony Sheehan, Dirk Welsford, Melissa Wheatley and Rod Watson. We thank Tony Fowler for constructive comments on the manuscript. This work was funded by Fisheries Research and Development Corporation of Australia grant No. 95/007 and the Australian Research Council

\section{LITERATURE CITED}

Bailey KM (1997) Structural dynamics and ecology of flatfish populations. J Sea Res 37:269-280

Baines PG, Fandry CB (1983) Annual cycle of the density field in Bass Strait. Aust J Mar Freshw Res 34:143-153

Bartsch J, Coombs S (1997) A numerical model of the dispersion of blue whiting larvae, Micromesistius poutassou (Risso), in the eastern North Atlantic. Fish Oceanogr 6: $141-154$

Black KP (1992) Evidence of the importance of deposition and winnowing of surficial sediments at a continental shelf scale. Cont Shelf Res 8:319-331

Black KP (1995) The hydrodynamic model 3DD and support software. Department of Earth Sciences, University of Waikato, Occasional Report 19

Black KP (1996) POL3DD lagrangian dispersal and sediment transport model and support software. Department of Earth Sciences, University of Waikato, Occasional Report 20

Bruce BD (1989) Studying larval fish ecology: benefits to King George whiting research. SAFISH 13:4-9

Bruce BD (1995) Larval development of King George whiting, Sillaginodes punctata, school whiting, Sillago bassensis, and yellow fin whiting, Sillago schomburgkii (Percoidei: Sillaginidae), from South Australian waters. Fish Bull 93: $27-43$

Champalbert G, Koutsikopoulos $C$ (1995) Behaviour, transport and recruitment of Bay of Biscay sole (Solea solea): laboratory and field studies. J Mar Biol Assoc UK 75 : 93-108

Currie DR, Parry GD (1999) Changes to benthic communities over 20 years in Port Phillip Bay, Victoria, Australia. Mar Pollut Bull 38:36-43

Dixon PI, Crozier RH, Black M, Church A (1987) Stock identification and discrimination of commercially important whitings in Australian waters using genetic criteria. Centre for Marine Science, University of New South Wales, FIRTA Project 87/117, Final Report

Doherty PJ, Planes S, Mather P (1995) Gene flow and larval duration in seven species of fish from the Great Barrier Reef. Ecology 76:2373-2391

Fowler AJ, McLeay L, Short DA (1999) Reproductive mode and spawning information based on gonad analysis for the King George whiting (Percoidei: Sillaginidae) from South Australia. Mar Freshw Res 50:1-14

Fowler AJ, Black KP, Jenkins GP (2000) Determination of spawning areas and larval advection pathways for King George whiting in southeastern Australia using otolith microstructure and hydrodynamic modelling. II. South Australia. Mar Ecol Prog Ser 199:243-254

Hammond LS, Black KP, Jenkins GP, Hodgkinson RS (1994) The influence of water circulation patterns in Bass Strait on recruitment success and stock differences in scallops. FIRTA Project 87/117. Final Report, Victorian Institute of Marine Sciences, Melbourne

Harris GP, Davies P, Nunez M, Neyers G (1988) Interannual variability in climate in Tasmania and its effect on freshwater and marine fisheries. Nature 333:754-757

Heath MR, Gallego A (1998) Bio-physical modelling of the early life stages of haddock, Melanogrammus aeglefinus, in the North Sea. Fish Oceanogr 7:110-125

Heath M, Brander K, Munk P, Rankine P (1991) Vertical distributions of autumn spawned larval herring (Clupea harengus $\mathrm{L}$.) in the North Sea. Cont Shelf Res 11:1425-1.452

Heath M, Zenitani H. Watanabe Y, Kimura R, Ishida M (1998) Modelling the dispersal of larval Japanese sardine, Sardinops melanostictus, by the Kuroshio Current in 1993 and 1994. Fish Oceanogr 7:335-346

Hyndes GA, Potter IC, Lenanton RCJ (1996) Habitat partitioning by whiting species (Sillaginidae) in coastal waters. Env Biol Fish 45:21-40

Hyndes GA, Platell ME, Potter IC, Lenanton RCJ (1998) Age composition, growth, reproductive biology, and recruitment of King George whiting. Sillaginodes punctata, in coastal waters of southwestern Australia. Fish Bull 96: $258-270$

Jenkins GP (1986) Composition, seasonality and distribution of ichthyoplankton in Port Phillip Bay, Victoria. Aust J Mar Freshw Res 37:507-520

Jenkins GP. Black KP (1994) Temporal variability in settlement of a coastal fish, the King George whiting, Sillaginodes punctata, is determined by low-frequency hydrodynamics. Limnol Oceanogr 39:1744-1754

Jenkins GP, May HMA (1994) Variation in settlement and larval duration of King George whiting, Sillaginodes punctata (Sillaginidae), in Swan Bay, Victoria, Australia. Bull Mar Sri 54:281-296

Jenkins GP, Black KP, Wheatley MJ, Hatton DN (1997) Temporal and spatial variability in recruitment of a temperate, seagrass-associated fish is largely determined by physical processes in the pre- and post-settlement phases. Mar Ecol Prog Ser 148:23-35

Jenkins GP, Keough MJ, Hamer PA (1998a) The contributions of habitat structure and larval supply to broad-scale recruitment variability in a temperate zone, seagrass-associated fish. J Exp Mar Biol Ecol 226:259-278

Jenkins GP, Welsford DC. Keough MJ, Hamer PA (1998b) Diurnal and tidal vertical migration of pre-settlement King George whiting Sillaginodes punctata in relation to feeding and vertical distribution of prey in a temperate bay. Mar Ecol Prog Ser 170:239-248

Jenkins GP, Black KP, Keough MJ (1999) The role of passive transport and the influence of vertical migration on the pre-settlement distribution of a temperate, demersal fish: model predictions compared with field sampling. Mar Ecol Prog Ser 184:259-271

McShane PE, Black KP, Smith MG (1988) Recrutment processes in Haliotus rubra (Mollusca: Gastropoda) and regional hydrodynamics in southeastern Australia imply localized dispersal of larvae. J Exp Mar Biol. Ecol 124 $175-205$

Middleton JF, Black KP (1994) The low frequency circulation in and around Bass Strait: a numerical study. Cont Shelf Res 14:1495-1521

Neilson JD, Perry RI (1990) Diel vertical migrations of marine 
fishes: an obligate or facultative process? Adv Mar Biol 26: $115-168$

Pawson MG, Jennings S (1996) A critique of methods for stock identification in marine capture fisheries. Fish Res 25:203-217

Prince JD, Sellers TL, Ford WB, Talbot SR (1987) Experimental evidence for limited dispersal of haliotid larvae (genus: Haliotis; Mollusca: Gastropoda). J Exp Mar Biol Ecol 106: 243-263

Proctor R, Wright PJ, Everitt A (1998) Modelling the transport of larval sandeels on the north-west European shelf. Fish Oceanogr 7:347-354

Robertson Al (1977) Ecology of juvenile King George whiting Sillaginodes punctatus (Cuvier and Valenciennes) (Pisces: Perciformes) in Western Port, Victoria. Aust J Mar Freshw Res 28:35-43

Editorial responsibility: Otto Kinne (Editor),

Oldendorf/Luhe, Germany
Sandars DF (1945) Five new microcotylids from fish from Western Australian waters. J Proc R Soc Western Aust 29:107-135

Sinclair M (1988) Marine populations: an essay on population regulation and speciation. University of Washington Press, Washington

Thresher RE (1994) Climatic cycles may help explain fish recruitment in south east Australia. Aust Fish 53:20-22

van der Veer $H W$, Ruardij $P$, Vandenberg AJ, Ridderinkhof $H$ (1998) Impact of interannual variability in hydrodynamic circulation on egg and larval transport of plaice Pleuronectes Platessa L. in the southern North Sea. J Sea Res 39:29-40

Wilson RS, Heislers S, Poore GCB (1998) Changes in benthic communities of Port Phillip Bay, Australia, between 1969 and 1995. Mar Freshw Res 49:847-861

Submitted: September 17, 1999; Accepted: December 7, 1999 Proofs received from author(s): June 5, 2000 